\title{
Chronic non-specific ulcerative duodenojejunoileitis: report of four cases
}

\author{
R. MOdigliani ${ }^{1}$, P. POItRAs, A. GAlian, B. MESSing, P. GUYET-ROUSSET, \\ M. LIBESKIND, J. L. PIEL-DESRUISSEAUX, AND J. C. RAMBAUD \\ From the Departments of Gastroenterology, and of Pathology, Hospital Saint-Lazare, and the \\ Departments of Gastroenterology and of Pathology, Hospital of Gonesse; and the Department of Surgery. \\ Hospital Lariboisière, Paris, France
}

SUMMARY Four patients with chronic non-specific ulcerative duodenojejunoileitis (CNSUDJI) are reported. The clinical picture included abdominal pain, fever, and a malabsorption syndrome. Main radiological findings were diffuse narrowing of the jejunal loops with total effacement of the mucosal folds. Multiple peroral biopsies of the small intestine showed various degrees of mucosal abnormalities from total villous atrophy to normal villi, but ulcerations were diagnosed only by operative full thickness biopsies or resection of the small bowel. The ulcerative process was associated with well-documented coeliac disease in two patients: in one of them it occurred as a fatal complication involving also the colon, three years after the start of a gluten free diet, while the disease was in full clinical and histological remission. In the other case, coeliac disease was revealed by obstructive symptoms due to stenosing ulcerations; five months after surgical resection of the stenosis, institution of a gluten free diet induced a dramatic improvement. In the two other patients ulcerations were not associated with coeliac disease: one of them had a patchy villous atrophy and resisted a gluten free diet and total parenteral nutrition; she was improved by and dependent upon steroids but finally died. The last patient had normal villous height; ulcerations were located exclusively along the mesenteric border of the small bowel; he had a low-grade protracted evolution resisting any form of therapy and developed a peripheral neuropathy of unknown aetiology. On the basis of our cases and of a review of the literature the discussion focuses on the difficulty in diagnosing CNSUDJI, its relationship with coeliac disease, and its management and prognosis.

Chronic non-specific ulcerative duodenojejunoileitis (CNSUDJI) is an entity characterised by the association of chronic ulcers of the small bowel with a malabsorption syndrome. Though initially described about 30 years ago (Nyman, 1949) this syndrome remains of unknown aetiology, uncertain nosology, and difficult diagnosis and treatment. We report here four patients with this disease who were seen in our department during the past five years.

\section{Case reports}

CASE 1

V.J., a 65 year old woman, was referred to Hospital Saint-Lazare in May 1973 for evaluation of ab-

${ }^{1}$ Address for reprint requests: R. Modigliani, Hospital Saint-Lazare, 107 rue du Faubourg Saint-Denis, 75475 Paris Cedex 10, France.

Received for publication 2 November 1978 dominal colic without diarrhoea, vomiting, $15 \mathrm{~kg}$ weight loss, and fever $\left(38^{\circ}-39^{\circ} \mathrm{C}\right)$ of six months' duration. Her past medical history was unremarkable, except for a low grade asthma (three to four short attacks per year) treated by oral betamethasone $(0.5 \mathrm{mg}$ at each attack). On physical examination, she appeared emaciated (weight $45 \mathrm{~kg}$; height $156 \mathrm{~cm}$ ), and chronically ill. Results of laboratory tests were haemoglobin $11.5 \mathrm{~g} / \mathrm{dl}$, WBC $5700 / \mu 1$ with a normal differential, ESR $22 \mathrm{~mm} / \mathrm{h}$. Absorption tests are reported in the Table. Serum immunoglobulin levels were $\operatorname{IgG} 9.2 \mathrm{~g} / 1(\mathrm{~N}=11.7 \pm 2.7$ mean $\pm \mathrm{SD}), \operatorname{IgA}$ $2.85 \mathrm{~g} / \mathrm{l}(\mathrm{N}=2.2 \pm 0.8)$, and $\mathrm{IgM} 1.5 \mathrm{~g} / \mathrm{l}(\mathrm{N}=$ $1 \cdot 2 \pm 0.5)$. HLA type was A2, A3 and BW5. A barium radiograph of the small intestine (Fig. 1) revealed total effacement of the mucosal pattern, scarce and coarsened folds with intervalvular spaces of varying width (up to $1 \mathrm{~cm}$ ), and spiculated margins in the jejunum; jejunal loops were diffusely narrowed but no ulcerations or stenosis were seen; the ileum 
Table Evolution of main parameters related to intestinal absorption in four cases of chronic non-specific ulcerative duodenojejunoileitis

\begin{tabular}{|c|c|c|c|c|c|c|c|c|c|c|c|c|c|}
\hline & \multirow{2}{*}{$\begin{array}{l}\text { Normal } \\
\text { values }\end{array}$} & \multicolumn{3}{|l|}{ Case 1} & \multicolumn{3}{|c|}{ Case 2} & \multicolumn{4}{|c|}{ Case 3} & \multicolumn{2}{|l|}{ Case 4} \\
\hline & & $\begin{array}{l}\text { May } \\
73\end{array}$ & $\begin{array}{l}\text { Jan. } \\
75\end{array}$ & $\begin{array}{l}\text { Aug. } \\
76\end{array}$ & $\begin{array}{l}\text { Dec. } \\
76\end{array}$ & $\begin{array}{l}\text { May } \\
77\end{array}$ & $\begin{array}{l}\text { Sept. } \\
77\end{array}$ & $\begin{array}{l}\text { Oct. } \\
75\end{array}$ & $\begin{array}{l}\text { Apr. } \\
76\end{array}$ & $\begin{array}{l}\text { Dec. } \\
76\end{array}$ & $\begin{array}{l}\text { July } \\
77\end{array}$ & $\begin{array}{l}\text { Nov. } \\
74\end{array}$ & $\begin{array}{l}\text { Apr. } \\
77\end{array}$ \\
\hline $\begin{array}{l}\text { Weight (kg) } \\
\text { Stool weight (g/24 h)* }\end{array}$ & $\overline{100}-200$ & $\begin{array}{l}45 \\
50\end{array}$ & $\begin{array}{l}51 \\
80\end{array}$ & $\begin{array}{l}48 \\
80\end{array}$ & $\begin{array}{r}41 \\
450\end{array}$ & $\begin{array}{r}39 \\
500\end{array}$ & $\begin{array}{r}59 \\
110\end{array}$ & $\begin{array}{r}46 \\
800\end{array}$ & $\begin{array}{r}44 \\
500\end{array}$ & $\begin{array}{r}51 \\
187\end{array}$ & $\begin{array}{r}44 \\
250\end{array}$ & $\begin{array}{r}33 \\
450\end{array}$ & $\begin{array}{r}36 \\
300\end{array}$ \\
\hline $\begin{array}{l}\text { Serum proteins }(\mathrm{g} / \mathrm{l}) \\
\text { Serum albumin }(\mathrm{g} / \mathrm{l}) \\
\text { Serum calcium }(\mathrm{mmol} / \mathrm{l}) \\
\text { Serum iron }(\mu \mathrm{mol} / \mathrm{l}) \\
\text { Serum folate }(\mu \mathrm{g} / \mathrm{l}) \dagger\end{array}$ & $\begin{array}{c}65-75 \\
35-45 \\
2 \cdot 25-2 \cdot 5 \\
14 \cdot 3-26 \cdot 8 \\
5=15\end{array}$ & $\begin{array}{l}35 \\
12 \\
1 \cdot 75 \\
6 \cdot 2 \\
2 \cdot 3\end{array}$ & $\begin{array}{c}62 \\
34 \\
2 \cdot 3 \\
\text { ND } \\
3\end{array}$ & $\begin{array}{l}61 \\
30 \\
2 \cdot 1 \\
2 \cdot 7 \\
2 \cdot 6\end{array}$ & $\begin{array}{l}60 \\
34 \\
1 \cdot 6 \\
\text { ND } \\
\text { ND }\end{array}$ & $\begin{array}{l}48 \\
24 \\
2 \\
7 \cdot 1 \\
3 \cdot 5\end{array}$ & $\begin{array}{r}57 \\
28 \cdot 5 \\
2 \cdot 2 \\
11 \cdot 7 \\
\text { ND }\end{array}$ & $\begin{array}{l}42 \\
14 \\
1 \cdot 8 \\
7 \cdot 1 \\
4 \cdot 4\end{array}$ & $\begin{array}{l}55 \\
24 \\
2 \cdot 05 \\
16 \cdot 1 \\
4 \cdot 3\end{array}$ & $\begin{array}{l}56 \\
27 \\
2 \cdot 2 \\
14 \cdot 7 \\
\text { ND }\end{array}$ & $\begin{array}{c}47 \\
24 \\
2 \\
6 \cdot 2 \\
\text { ND }\end{array}$ & $\begin{array}{l}54 \\
28 \\
2 \cdot 05 \\
17 \cdot 9 \\
9 \cdot 6\end{array}$ & $\begin{array}{c}50 \\
22 \cdot 5 \\
2 \cdot 0 \\
8 \cdot 9 \\
\text { ND }\end{array}$ \\
\hline $\begin{array}{l}\text { D-xylose test }(\mathrm{mg} / \mathrm{l}) \ddagger \\
\text { FATT }(\mu \mathrm{g} / \mathrm{l}) \S \\
\text { Schilling test }(\%) q \\
\text { Faecal fat }(\mathrm{g} / 24 \mathrm{~h})^{*} \\
\text { Faecal nitrogen }(\mathrm{g} / 24 \mathrm{~h})^{*}\end{array}$ & $\begin{array}{l}>250 \\
>\quad 40 \\
>\quad 8 \\
<\quad 6 \\
<\quad 2\end{array}$ & $\begin{array}{c}168 \\
10 \\
9 \cdot 2 \\
2 \cdot 1 \\
0 \cdot 3\end{array}$ & $\begin{array}{c}308 \\
70 \\
17 \\
2 \\
0.5\end{array}$ & $\begin{array}{l}300 \\
\text { ND } \\
\text { ND } \\
2 \cdot 6 \\
0.9\end{array}$ & $\begin{array}{c}107 \\
\text { ND } \\
\text { ND } \\
9 \cdot 5 \\
\text { ND }\end{array}$ & $\begin{array}{c}16 \\
\text { ND } \\
0 \cdot 8 \\
26 \\
2 \cdot 8\end{array}$ & $\begin{array}{r}136 \\
\text { ND } \\
4.6 \\
6.5 \\
1.0\end{array}$ & $\begin{array}{r}148 \\
12 \\
9 \cdot 3 \\
35 \cdot 5 \\
3 \cdot 3\end{array}$ & $\begin{array}{r}84 \\
16 \\
6.9 \\
33.3 \\
5.4\end{array}$ & $\begin{array}{c}330 \\
\text { ND } \\
19 \\
15 \cdot 7 \\
2 \cdot 1\end{array}$ & $\begin{array}{l}128 \\
\text { ND } \\
\text { ND } \\
\text { ND } \\
\text { ND }\end{array}$ & $\begin{array}{r}210 \\
12 \\
1 \cdot 0 \\
12 \cdot 2 \\
2 \cdot 1\end{array}$ & $\begin{array}{c}320 \\
\text { ND } \\
0.6 \\
36 \\
2.6\end{array}$ \\
\hline${ }^{1} \mathrm{Cr}$ albumin test $(\mathrm{ml} / 24 \mathrm{~h})$ & $<45$ & 187 & ND & 142 & ND & ND & ND & ND & ND & 144 & ND & ND & ND \\
\hline
\end{tabular}

* Mean of three-day stool collection.

†Assay by Lactobacillus casei.

$\ddagger$ Blood xylose level 120 minutes after ingestion of $25 \mathrm{~g}$ xylose.

§Folic acid tolerance test (presaturation by $10 \mathrm{mg}$ calcium folate intramuscularly; oral load of $40 \mu \mathrm{g}$ per kg body weight of folic acid; blood sampling at 60 and 90 minutes; assay by Streptococcus faecalis).

$q$ Percentage of QI excreted in 24 hour-urines; radioactive vitamin B 12 was given with intrinsic factor.

$\mathrm{ND}=$ not done.

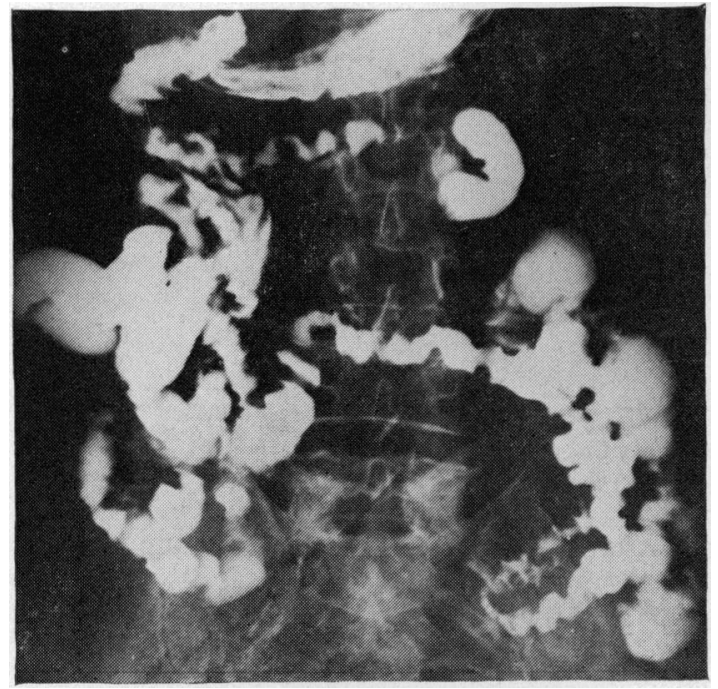

Fig. 1 Case 1. Radiograph of upper gastrointestinal tract. The 10 minute film shows diffusely narrowed jejunum with effacement of the normal mucosal pattern.

was normal. Three peroral biopsies were taken from ileum to duodenum and showed on histological examination total villous atrophy with a cuboidal lining epithelium, elongated crypts with an increased number of mitosis, and numerous plasma cells in the lamina propria (Fig. 2). On immunofluorescence there was an increased number of IgM plasma cells, whereas IgA and IgG cell populations seemed normal. The patient was treated by total parenteral nutrition (TPN) during three months, followed by a gluten-free diet to which she adhered carefully. Complete clinical, biological (Table), and histological (Fig. 3) remission was documented in January 1975. Yet radiographs of the small bowel remained unchanged. In June 1976, she took $0.5 \mathrm{mg}$ oral betamethasone during four days (without potassium supplements) for an attack of asthma. In August 1976, while she was still adhering carefully to her gluten free diet, abdominal pain, asthenia, and fever recurred. On examination, she looked tired and the tip of the spleen was palpable. Results of laboratory tests were haemoglobin $14.5 \mathrm{~g} / \mathrm{dl}$, WBC $11800 / \mu \mathrm{l}$ with a normal differential, ESR $32 \mathrm{~mm} / \mathrm{h}$. Absorption tests are shown in the Table. Serum immunoelectrophoresis, IgG, IgA, IgM, and total complement levels were normal; no cryoglobulinemia was detected. Oesogastroduodenoscopy was normal. Radiographs of the small intestine were still unchanged. Three specimens of intestinal mucosa (proximal, mid, and distal jejunum) were found to be normal. A lymphoma was suspected and a laparotomy was undertaken: a $90 \mathrm{~cm}$ segment of midjejunum showed thickening of the bowel wall; the rest of the small bowel and of other abdominal organs was unremarkable. A $3 \mathrm{~cm}$-long mid-jejunal resection, a full thickness ileal biopsy, mesenteric nodes excision, liver biopsy, and splenectomy were performed. Multiple and extensive ulcerations lying on the middle part of the submucosa without undermining of the remaining mucosa were found at histo- 


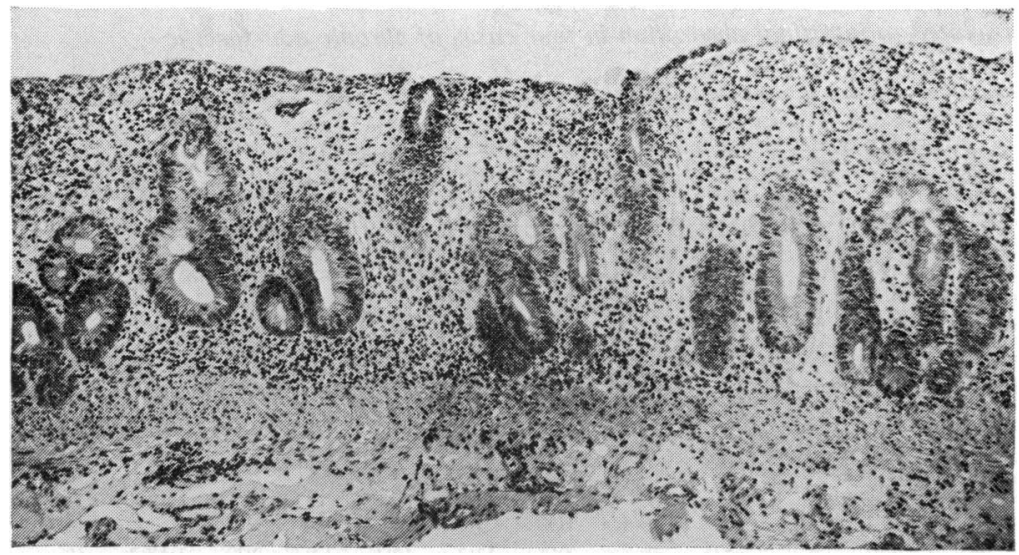

Fig. 2 Case 1. Peroral jejunal biopsy specimen before treatment. The mucosa shows total villous atrophy, desquamated lining epithelium, and dense cellular infiltrate of the lamina propria. Haematoxylin-eosin-saffron, $\times 120$.

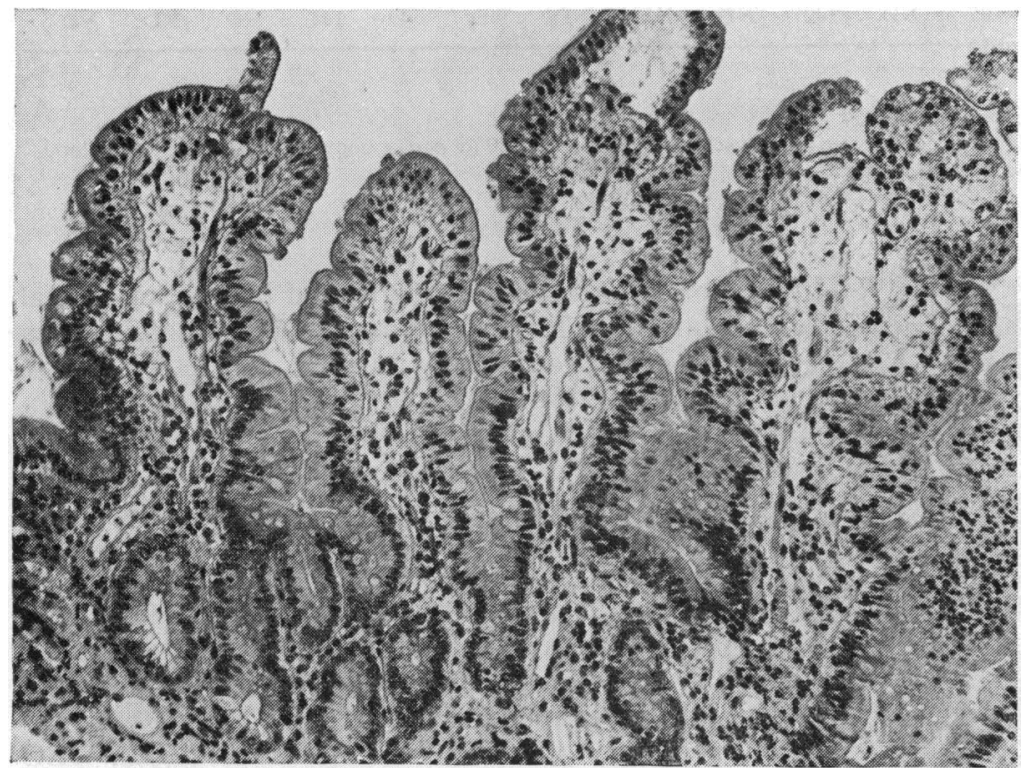

Fig. 3 Case 1. Peroral jejunal biopsy specimen taken after 20 months on a gluten free diet. Normalmucosa. Haematoxylineosin-saffron, $\times 225$.

logical examination of the jejunal specimen (Fig. 4). The bed of the ulcers showed a slight sclerosis with numerous capillaries and non-specific inflammatory cells; in the scarce areas of intervening non-ulcerated areas, there was a total villous atrophy; a few aspects of antral metaplasia and numerous crypt abcesses were seen. The muscular and serosal layers were normal. Search for siderophages was negative. Histological study of ileal and hepatic biopsies and of the spleen showed no significant abnormalities and mesenteric nodes were the site of non-specific stimulation. Her postoperative course was complicated by a septic subclavian thrombophlebitis and the patient died in November 1976. At post-mortem examination an extensive ulceration identical to that previously described was found in the mid-jejunum; autolysis precluded appreciation of villus height. Numerous similar ulcerations and erosions were scattered throughout the rectum and the colon with an aspect of colitis cystica superficialis in the intervening mucosa (Fig. 5). No other abnormalities were found.

\section{CASE 2}

Y.J., a 47 year old woman, complained of intermittent diarrhoea since May 1976; in December 1976 she was admitted to another hospital because of abdominal colic and $9 \mathrm{~kg}$ weight loss. Physical examination was normal. Routine laboratory tests were normal. Results of absorption tests are given in the Table. Upper gastrointestinal series showed disappearance of proximal jejunal folds and multiple 


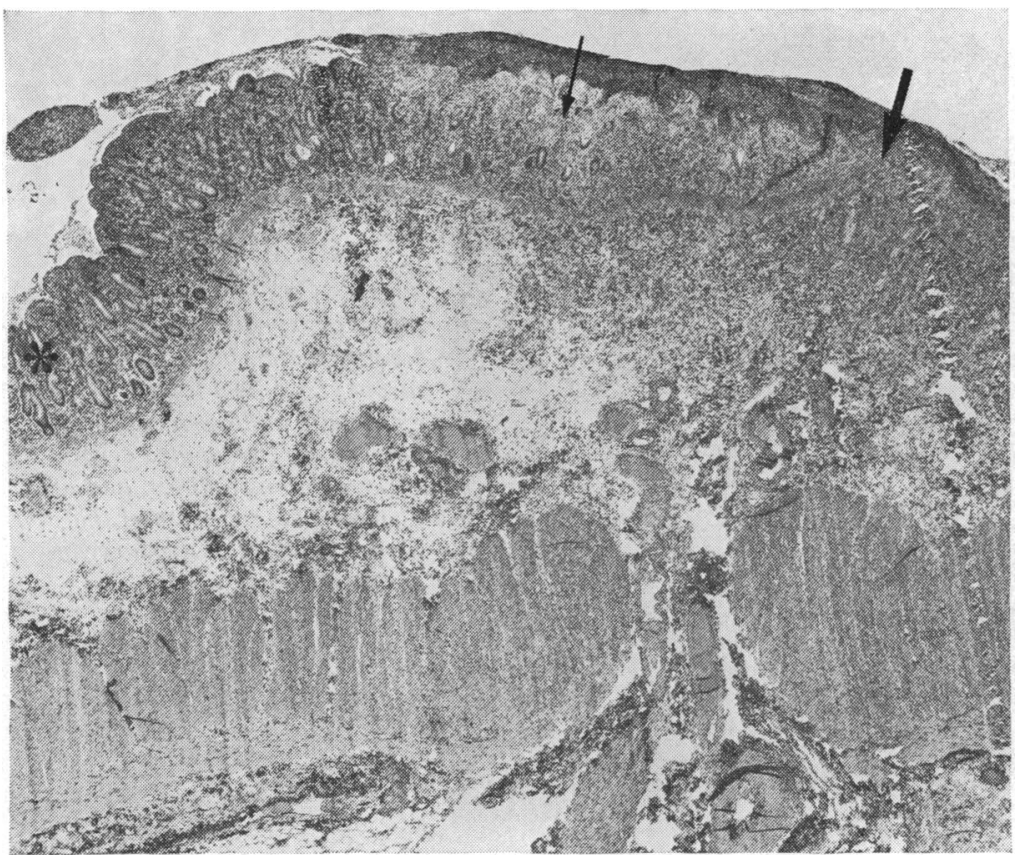

Fig. 4 Case 1. Surgical specimen of the jejunum. From left to right can be seen atrophic mucosa $\left({ }^{*}\right)$, erosion (thin arrow) and ulceration (thick arrow). Haematoxylin-eosin-saffron $\times 30$.

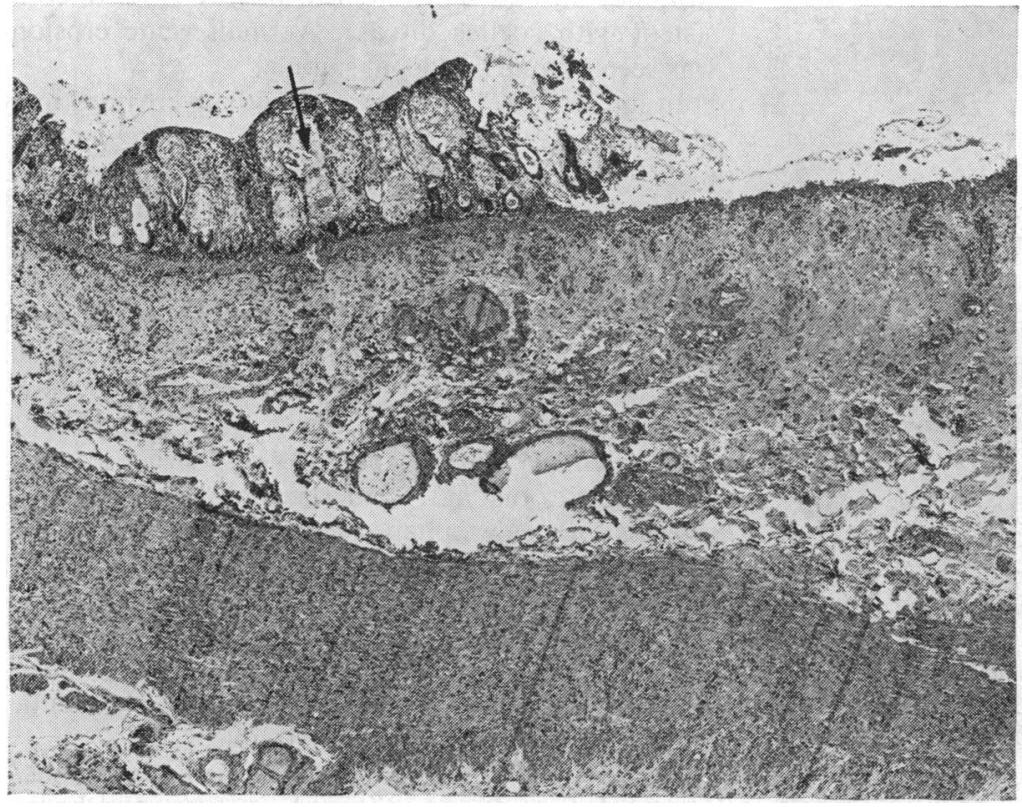

Fig. 5 Case 1. Necropsy specimen of the colon. It shows cystic dilatation of the colonic glands (arrow) with an adjacent ulceration. Haematoxylin-eosinsaffron, $\times 36$.

stenosis of the distal jejunum, but no obvious ulcerations. At jejunoscopy as far as $40 \mathrm{~cm}$ beyond the angle of Treitz, the mucosa appeared erythematous but not ulcerated; however, four small whitish areas suggesting pseudomembranes were seen in the duodenum. Seven forceps biopsies obtained from 


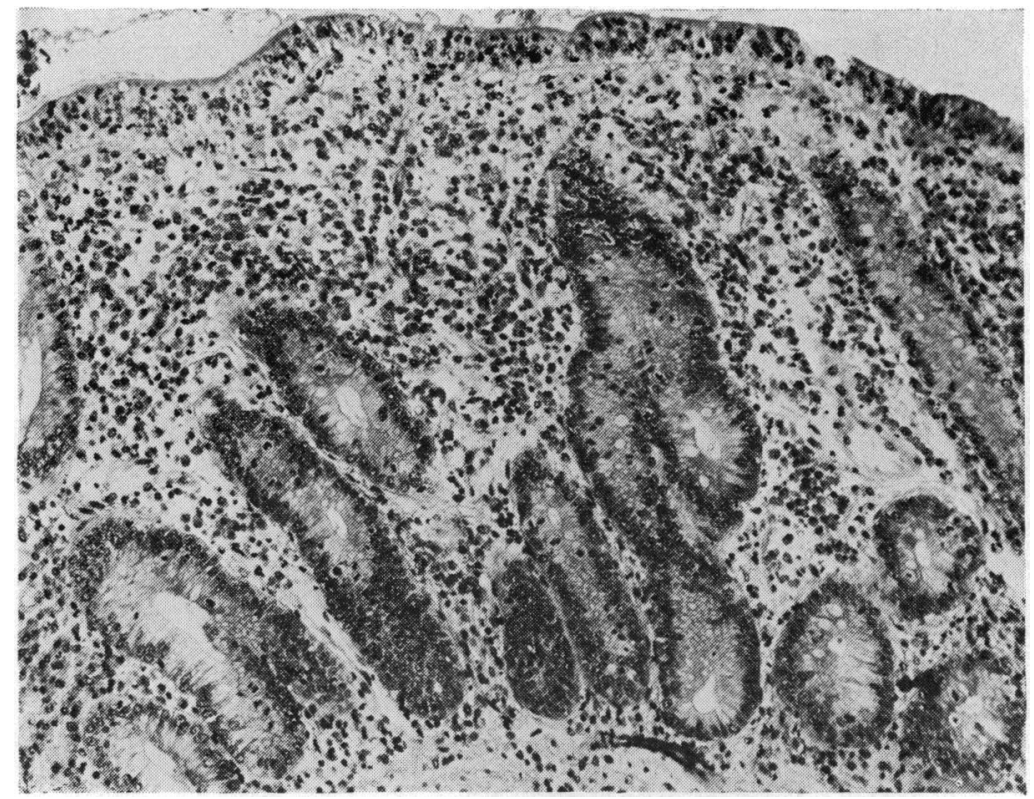

Fig. 6 Case 2. Peroral biopsy of the proximal jejunum before treatment showing total villous atrophy, cuboidal lining epithelium infiltrated with lymphocytes, elongated crypts with numerous mitoses, and a pleiomorphic infiltrate of the lamina propria. Haematoxylineosin-saffron, $\times 210$.

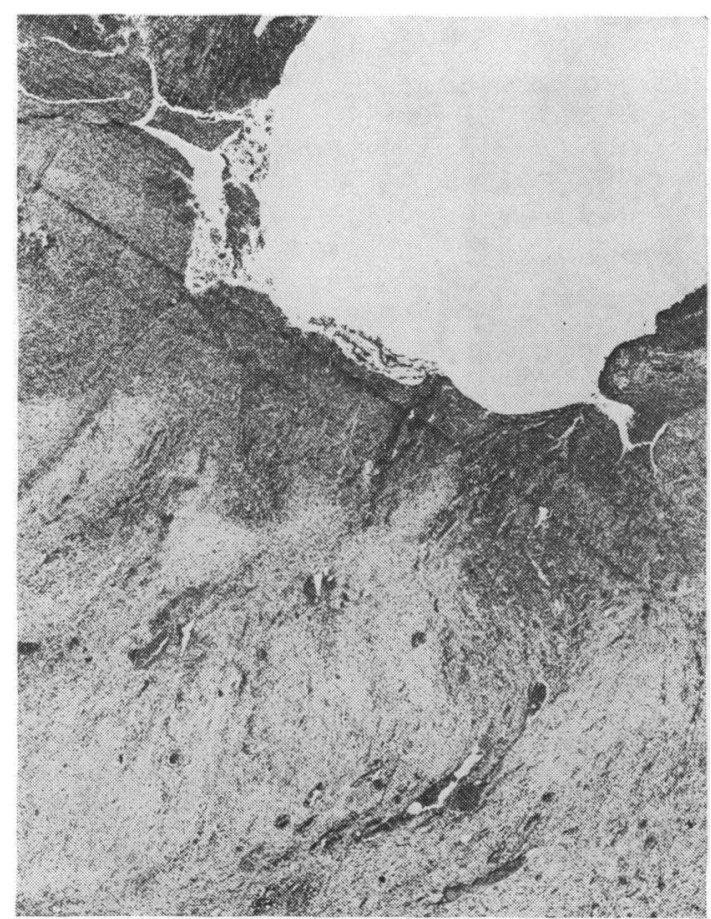

Fig. 7 Case 2. Surgical specimen of the mid jejunum showing a chronic ulceration. Haematoxylin-eosin saffron, $\times 210$. the proximal jejunum and the duodenum (Dr C. Marche) showed a histological picture (Fig. 6) consistent with coeliac disease. A small acute erosion was seen on one duodenal sample.

In January 1977 she presented with severe intestinal obstruction and was operated on: three circular and ulcerated stenosis were found in the distal jejunum; $1 \mathrm{~m}$ of mid small bowel was resected. Histologically (Fig. 7) the ulcerations (one of which was fissuring) lay on the muscular or serosal coat and consisted of a superficial layer of necrosis and polymorphs exudate overlying a vascular connective tissue heavily infiltrated with inflammatory cells; the bottom of the ulcerations was occupied by a prominent sclerosis with a few medium sized arteries showing chronic and sometimes obliterative endarteritis; no siderophages could be found; a few lymphoid nodules were scattered throughout the sclerosis and a single tuberculoid granuloma was seen adjacent to a necrotic area; pyloric gland metaplasia was observed on the ulcer edge. In the nonulcerated areas the mucosa showed normal villi. Mesenteric nodes were unremarkable.

Postoperatively the obstructive symptoms disappeared but she experienced profuse diarrhoea, tetany, and ankle oedema. When first seen at Hospital Saint-Lazare in May 1977, she weighed $39 \mathrm{~kg}$ (height $154 \mathrm{~cm}$ ); physical examination was otherwise unremarkable. One of her nephews was 
treated for well-documented coeliac disease. Routine laboratory tests were normal except for hypokalemia $(2.1 \mathrm{mM} / \mathrm{l})$; serum gastrin level was normal. Absorption tests are reported in the Table. IgG, A, and M serum levels were respectively $7 \cdot 5,2.85$, and $1.35 \mathrm{~g} / 1$. HLA type was A2, A3, B8, and BW22. Radiographs of the small intestine showed enlarged duodenal folds, slight dilatation of the jejunal loops with moderately thickened and straight valvulae, and markedly widened intervalvular spaces; there was no evidence of stenosis or ulceration. Jejunoscopy down to the third jejunal loop showed no ulcerated areas. Four biopsies from the proximal jejunum and duodenum revealed a picture identical with that observed in the specimens taken at the first jejunoscopy, but without erosions. Rectosigmoidoscopy and rectal biopsy were normal. A gluten free diet alone induced a dramatic clinical improvement $(+8 \mathrm{~kg}$; normal stool weight) within three weeks. After four months of gluten withdrawal, the patient had put on $20 \mathrm{~kg}$ and passed one normal stool per day. The biological improvement is shown in the Table. The patient declined a further jejunal biopsy.

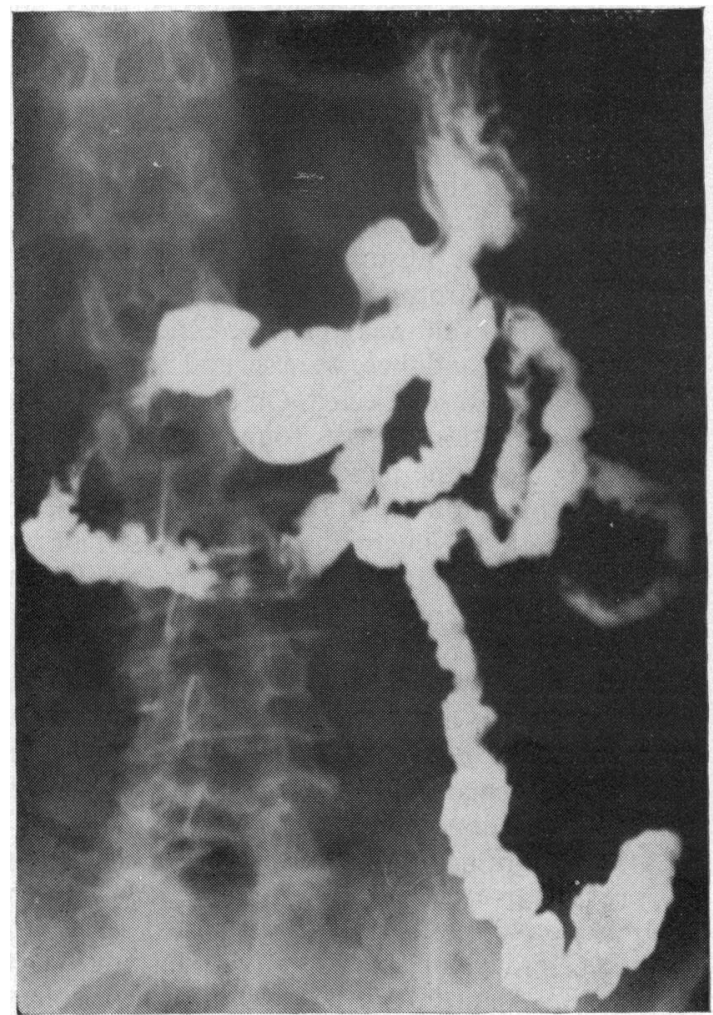

Fig. 8 Case 3. Radiograph of upper gastrointestinal tract showing diffuse narrowing and effacement of the mucosal folds in the proximal small bowel.
CASÉ 3

R.Y. attended Hospital Saint-Lazare in October 1975 at the age of 61 years with a four months' history of diarrhoea, abdominal pain, weight loss $(10 \mathrm{~kg})$, recurrent leg thrombophlebitis, and fever. Physical examination revealed a new thrombophlebitis and a poor general condition that required immediate treatment by TPN and heparin. Laboratory tests included a haemoglobin of $10.8 \mathrm{~g} / \mathrm{dl}$, a WBC of $9900 / \mu$ l with $82 \%$ neutrophils, and an ESR of $38 \mathrm{~mm} / \mathrm{h}$. Results of absorption tests are shown in the Table. Bacterial overgrowth $\left(E\right.$. coli $10^{6} / \mathrm{ml}$, Lactobacilli $10^{6} / \mathrm{ml}$ ) was found in the proximal jejunum. Serum IgG, $A$, and $M$ levels were respectively $8.5,3.75$, and $0 \mathrm{~g} / \mathrm{l}$ but a few days later IgM was only moderately decreased on immunoelectrophoresis. Search for cryoglobulinaemia was negative and total complement level was normal. HLA type was A1, A9, B13, and B18. Upper digestive endoscopy revealed two minute ulcerations of the second part of the duodenum. Radiographs of the small intestine showed that the barium reached the caecum within 15 minutes; jejunal loops were diffusely narrowed with total effacement of the mucosal pattern (Fig. 8). There were no radiographically visible ulcerations. Ten peroral biopsies were obtained from mid-jejunum to duodenum and showed patchy lesions (Fig. 9): the villous pattern ranged from subtotal villous atrophy to normally tall villi with variable shapes, frequent broadening and distortion; the lining epithelium was normal or cuboidal; crypt arrangement was irregular with clumps of glands in enlarged interglandular spaces. Two crypt abcesses were observed. The lamina propria was infiltrated with numerous plasma cells, neutrophils, and eosinophils. On immunofluorescence the density of IgAproducing cells was greatly increased; that of IgM and IgG cells was moderately increased and normal respectively. On the whole, the lesions did not predominate in the proximal samples and one of the duodenal biopsies had normal villi.

Fifty-three days of TPN improved the nutritional status but did not change small intestinal function and histology. After the failure (Table) of a sixmonth strict gluten free diet and oral antibiotics (ampicillin, streptomycin) a laparotomy was performed in June 1976. The small bowel, as all other abdominal contents, looked normal. Four full thickness biopsies were taken from proximal and distal jejunum and ileum. Several patterns coexisted on each of the specimens: normal mucosa, scarred ulcerations as shown on Fig. 10; active ulcerations. Granulomas, vascular lesions, and siderophages were absent. Liver biopsy showed only triaditis and mesenteric nodes were normal.

Prednisone (50 mg/day) was then added to previous 


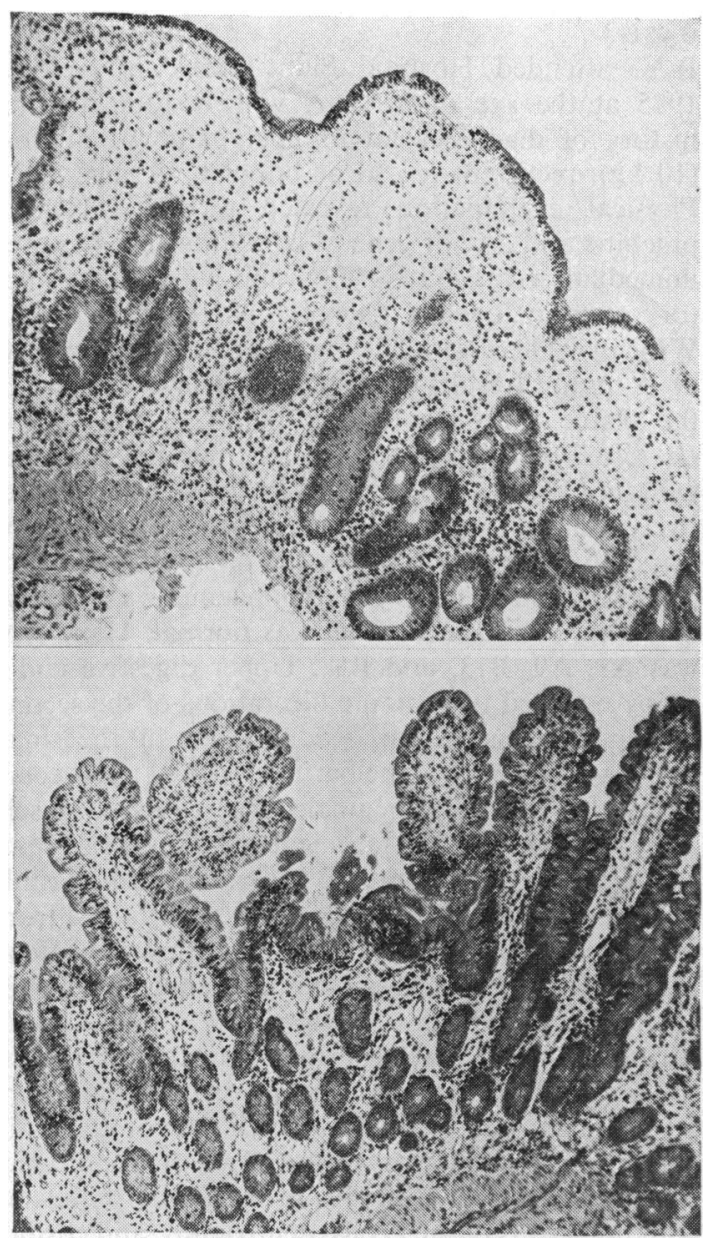

Fig. 9 Case 3. (Top). Peroral biopsy taken at the angle of Treitz and showing a dystrophic mucosa with very short and irregular villi and clumps of disorted crypts. (Bottom). Peroral biopsy taken from the duodenum showing a normal mucosa. Haematoxylin-eosin-saffron, $\times 120$.

treatment and the patient soon improved. Six months later (December 1976) laboratory tests showed marked improvement (Table). Serum immunoglobulins were then normal. In May 1977 antibiotics were discontinued and steroids reduced to $15 \mathrm{mg}$ per day. A severe relapse necessitated a new course of TPN, antibiotics, and increased dosage of prednisone (30 mg daily). The attack subsided rapidly but the patient suddenly died on 21 August 1977. At postmortem examination lesions were limited to the small bowel (except for pulmonary oedema and an inferior vena cava thrombosis) and predominated in the distal jejunum; they consisted of multiple reepithelialised erosions and ulcerations (identical with those described on operative biopsies) with rare areas of normal intervening mucosa.

\section{CASE 4}

This case has been already reported in detail elsewhere (Belaiche et al., 1977) and will be summarised here. N.K., a 28 year old Algerian male, complained of frequent diarrhoea and vomiting since the age of 10 years without detectable aetiology despite numerous investigations in several other hospitals. Multiple therapeutic trials (gluten free diet for three months, oral tetracycline and metronidazole) had been unsuccessful. When first seen at Hospital SaintLazare in November 1974, he was in a poor nutritional state $(33 \mathrm{~kg} ; 160 \mathrm{~cm})$ and had digital clubbing. Laboratory values were haemoglobin $9 \cdot 4 \mathrm{~g} / \mathrm{dl}$, WBC $6300 / \mu l$ with a normal differential, ESR $35 \mathrm{~mm} / \mathrm{h}$. Other routine biological investigations were normal. Results of absorption studies are reported in the Table. Pancreatic enzymatic response to a Lundh meal was normal and fasting jejunal fluid was sterile. Serum gastrin was normal. Immunoelectrophoresis using a monospecific antiserum to $\operatorname{IgA}$ ruled out $\alpha$-chain disease and serum levels of IgG, $\mathrm{A}$, and $\mathbf{M}$ were normal. HLA type was A9, ADa25, BW5, and B12. Radiographs of the small intestine showed total effacement of the mucosal pattern without ulcerations. Oesogastroduodenoscopy and colonoscopy were normal. Multiple duodenal, jejunal, and colonic biopsies showed no abnormalities. Fifty-six days of TPN greatly improved the patient's nutritional status but absorption tests remained unchanged. At laparotomy (January 1975) the distal small intestine wall was thickened along its mesenteric insertion and there were several ileal stenoses: $90 \mathrm{~cm}$ of ileum were resected. On opening the bowel multiple ulcerations were found to be located exclusively along the mesenteric attachment. Histological examination (Fig. 11) revealed non-specific active ulcerations lying on the submucosa, which was very vascular, infiltrated with inflammatory cells, and underlined by sclerosis. At the edge of the ulcerations villi were irregular but not atrophic and a few crypts showed antral metaplasia. A few re-epithelialised ulcerations were also seen. Vascular abnormalities, granulomas, and siderophages were absent. The intervening mucosa was normal and mesenteric nodes showed non-specific stimulation.

After a slight improvement the patient returned to his preoperative status; he received successively oral prednisone $(40 \mathrm{mg} /$ day for two months), oral tetracycline ( $2 \mathrm{~g} /$ day for six weeks) without any benefit (Table). In August 1977 he developed a peripheral neuropathy predominating in the legs, and the aetiology of which remained obscure: there was no alcoholism, normal B12 and folate serum levels, 


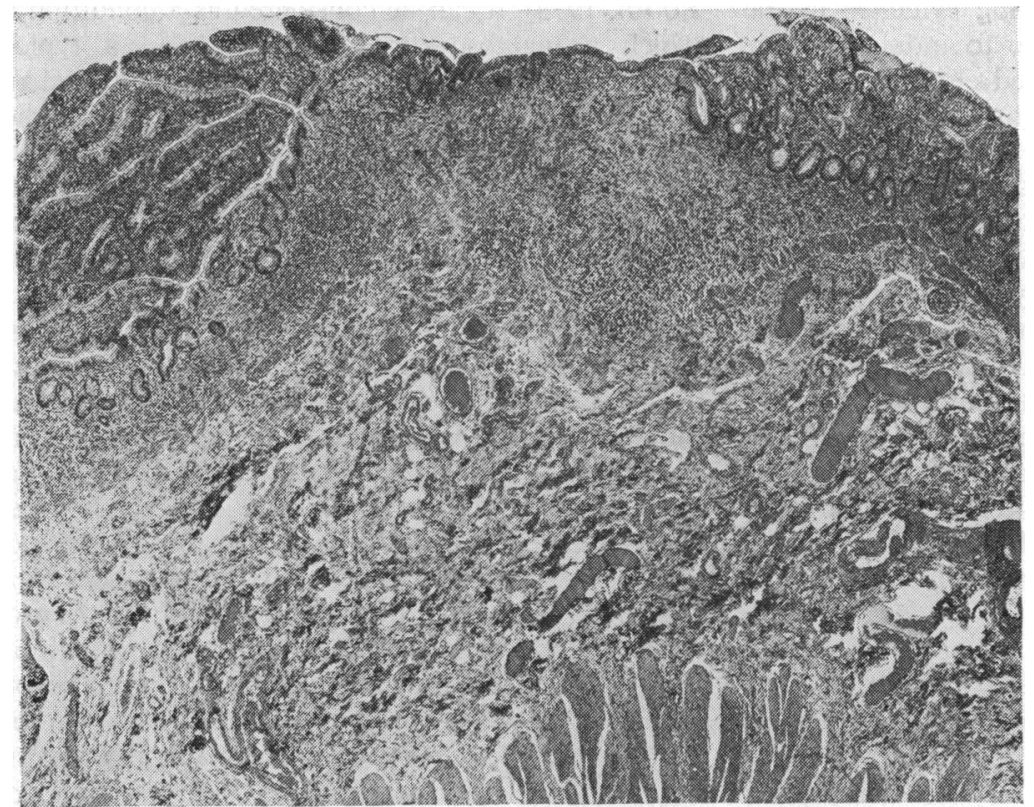

Fig. 10 Case 3. Surgical biopsy from the mid jejunum showing a re-epithelialised ulceration. Haematoxylin-eosin-saffron, $\times 35$.

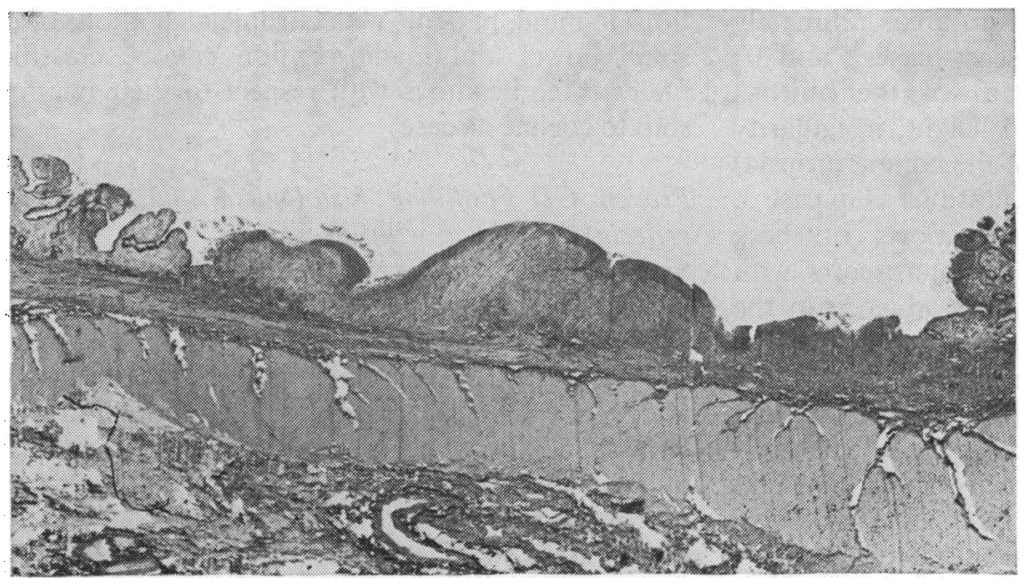

Fig. 11 Case 4. Ileal resection. Chronic ulceration surrounded by dystrophic mucosa. Haematoxylin-eosin-saffron, $\times 14$.

unspecific abnormalities of peripheral nerves without inflammatory infiltrate or evidence of vasculitis or amyloidosis at neuromuscular biopsy, and normal CSF. High doses of intramuscular vitamin B1 and B6 induced a questionable improvement.

\section{Discussion}

Our patients had in common a malabsorption syndrome and anatomically documented multiple :ulcerations of the small bowel (and of the colon in case 1). None of the known causes of chronic ulcerations of the small bowel (Bayless et al., 1967; Wayte and Helwig, 1968) could be found despite extensive investigations. In case 2 the familial history of coeliac disease, the total villous atrophy in the proximal jejunum and the dramatic response to a gluten free diet rule out Crohn's disease, in spite of the presence on the resected specimen of one fissure and a single tuberculoid granuloma. Patient 1 had been on low doses of corticosteroids for four days, a few weeks before the clinical relapse due to ulcera- 
tions. Yet there is no convincing evidence in the literature that steroids are able to induce chronic intestinal ulcerations, as discussed elsewhere (Modigliani, 1977). Our cases can thus be classified as chronic non-specific ulcerative duodenojejunoileitis (CNSUDJI). Since the first report by Nyman (1949) 39 such cases, including these, have been reported with some detail in the English and French literature. Major clinical features of this syndrome are chronic diarrhoea, malabsorption, exudative enteropathy, abdominal pain, fever, and surgical complications (stenosis, perforation, and bleeding) leading frequently to repeated operations and eventually death. The following discussion will focus on three points which are well illustrated by our cases: the difficulty in diagnosis, the relationship of this syndrome with coeliac disease and the management of CNSUDJI.

\section{DIAGNOSIS}

The diagnosis of this syndrome is difficult. (1) The clinical, biological, and radiological picture is aspecific. The ulcerations have been detected radiologically in only four patients (Bayless et al., 1967; Neale, 1970; Stuber et al., 1971; Seliger et al., 1973). (2) Except on one occasion (Patterson et al., 1966), blind biopsies of the small intestine have never documented the ulcerations even if taken at multiple levels (cases 1, 3, and 4) and from areas ultimately proved to be involved by the disease (cases 1 and 3); however, the dystrophic pattern of the mucosa (variability of villous shape and height, irregularity of crypt distribution, sclerosis of the lamina propria) may be suggestive of scarred ulcerations as in case 3 . (3) As proved by two recent case reports (Lotsberg et al., 1976; Cerf et al., 1977), enteroscopy with guided biopsies represents a major advance in the diagnosis of CNSUDJI but does not preclude the need for laparotomy to establish the nature of the ulcerations. (4) Indeed, in all but one patient (Lotsberg et al., 1976), the diagnosis has been ascertained only after laparotomy (or necropsy) and histological examination of full thickness biopsies or resection specimens. The serosal surface may look normal at operation (Seliger et al., 1973; Cerf et al., 1977; Gouffier et al., 1977; our case 3); peroperative enteroscopy might thus be of value to locate ulcerations and guide surgical sampling (Gouffier et al., 1977). Thus a laparotomy with peroperative endoscopy and biopsies is presently the most reliable diagnostic procedure.

\section{RELATIONSHIP WITH COELIAC DISEASE}

The relationship between CNSUDJI and coeliac disease is not clear (Bayless et al., 1974). Although a universally agreed definition of coeliac disease has not been achieved (Cooke and Asquith, 1974;
Booth, 1974), it can be considered as a condition in which a malabsorption syndrome and a typical pathological pattern of the proximal small bowel are associated and which improves on a gluten free diet (Trier, 1973). When discussing the relationship of this disease with CNSUDJI one is faced with problems concerning both the morphological and therapeutic criteria: (1) patchy villous atrophy with completely flat mucosa next to normal villi is frequent in CNSUDJI (Jeffries et al., 1968; our case 3 ); a single peroral biopsy showing total villous atrophy may thus falsely suggest coeliac disease; multiple peroral biopsies are, in fact, crucial, as illustrated by case 3 in which three out of 10 mucosal samples showed a completely flat mucosa, whereas the presence of normal villi in other samples, one of which was duodenal, ruled out the disease. (2) A trial of a gluten free diet implies a sufficiently prolonged period of complete gluten exclusion with, at best, a morphological documentation of its effect; associated steroids may obscure the interpretation of this trial. These morphological and therapeutic requirements are rarely fulfilled and the lack of relevant information precludes further discussion of some of the published cases (Nyman, 1949; Himes et al., 1957; Smitskamp and Kuipers, 1965; Moritz et al., 1971; Seliger et al., 1973). With these limitations in mind, patients with chronic ulcerations of the small bowel and malabsorption can be classified under three headings with respect to their relationship to coeliac disease:

Proven CD (fulfilling histological and therapeutic criteria) associated with ulcerations

Six such cases (Bayless et al., 1967; Davidson, 1969; Neale, 1970; Dowling, 1972; Jones and Gleeson, 1973; Klaeveman et al., 1975) have been already fully reported, to which our patients 1 and 2 can be added. Two similar cases are briefly mentioned by Hindle and Creamer (1965). Among the eight cases published with some detail the ulcerative process revealed coeliac disease by a surgical complication in two patients (Davidson, 1969; our case 2), was discovered at the same time as (Jones and Gleeson, 1973), or a few months after coeliac disease (Neale, 1970; Dowling, 1972; Klaeveman et al., 1975) in four instances; in two cases (Bayless et al., 1967; our case 1) a gluten free diet had been strictly followed for several years and the mucosa had returned to normal when ulcerations occurred; furthermore, in our case 2, the ulcerations developed in the distal jejunum, an area where the intervening mucosa had normal villi. These findings suggest that the ulcerative process of coeliac disease is not gluten-induced and does not require villous atrophy to develop. The presence of an obliterative arteritis in the ulcerations 
of case 2 is probably a secondary phenomenon. The involvement of the colon in the ulcerative process, as in case 1 , is a rare but already reported possibility (Dowling, 1972).

Possible CD associated with small bowel ulcerations This group includes 11 patients with total or subtotal villous atrophy of the proximal jejunum but in whom gluten withdrawal had no effect (Shiner, 1963; Goulston et al., case 2 and 3, 1965; Stuber et al., 1971; Corlin and Pops, 1972; Armstrong et al., 1973) or was unappreciable (London et al., 1961; Cerf et al., 1977); a gluten free diet was not prescribed in three of them (Goulston et al., case 1 and 4, 1965; Lotsberg et al., 1976). None of our patients belonged to this group. Search for a family history of coeliac disease, HLA typing and organ culture of jejunal biopsy specimen (Klaeveman et al., 1975) might be helpful in these difficult cases.

Chronic ulcerations of small bowel and no coeliac disease (true idiopathic CNSUDJI)

In this group of 10 patients the histological picture rules out coeliac disease, as it shows either entirely normal villi (Patterson et al., 1966; Case Records of the Massachusetts General Hospital, 1969; Karz et al., 1971; Gouffier et al., 1977; our case 4) or a patchy villous atrophy with adjacent areas of entirely normal and flat mucosa (Jeffries et al., 1968; Gouerou et al., 1977; our case 3). Our case 4 is unusual because of (1) its protracted evolution extending over 18 years; (2) the location of the ulcerations only along the mesenteric border of the intestine; and (3) the recent occurrence of a peripheral neuropathy of unknown aetiology but apparently different from the neurological disorder which may complicate the course of coeliac disease (Cooke and Smith, 1966; Bernier et al., 1976).

\section{TREATMENT}

Treatment of CNSUDJI is difficult for the following reasons.

Many of these patients come to surgery because of stenosis, haemorrhage, or perforation: out of 12 patients who were followed up after resection of the whole (or supposedly so) abnormal area, five died (Goulston et al., case 2, 1965; Case Records of the Massachusetts General Hospital, 1969; Neale, 1970; Karz et al., 1971; Armstrong et al., 1973), two did not improve until they were put on steroids (Klaeveman et al., 1975) or a gluten free diet (our case 2), and one remained unchanged (our case 4). The four remaining subjects had a favourable outcome but received a gluten free diet immediately after surgery (Hindle and Creamer, 1965; Davidson, 1969; Moritz et al., 1971).
Gluten withdrawal is beneficial (sometimes dramatically, as in case 2) to a few patients with villous atrophy of the proximal small bowel but only after the ulcerative process has been controlled by steroids (Jones and Gleeson, 1973) or surgery (Hindle and Creamer, 1965; Davidson, 1969; Moritz et al., 1971; our case 2). A gluten free diet does not seem to influence or prevent the ulcerative process itself.

Corticosteroids are useful in a limited number of patients with ulcerations and proven coeliac disease (Jones and Gleeson, 1973; Klaeveman et al., 1975), possible coeliac disease (Goulston et al., case 4, 1965; Lotsberg et al., 1976), and no coeliac disease (Jeffries et al., 1968; our case 3).

Exclusive parenteral feeding can overcome severe nutritional distress, as in our cases 3 and 4 , but failed in these patients to improve small intestinal function and morphology, though prolonged for 53 and 56 days respectively.

The general prognosis of CNSUDJI is poor, as 17 of the 30 patients whose follow-up has been published are dead at the time of publication. Six of the survivors come from the coeliac disease group: four are well on a gluten free diet alone (Hindle and Creamer, 1965; Jones and Gleeson, 1973; our case 2); one needs maintenance corticotherapy (Klaeveman et al., 1975) and the last had a second perforation after giving up a gluten free diet (Davidson, 1969). None of the four survivors of the group with possible coeliac disease has fully recovered (Goulston et al., case 4, 1965; Corlin and Pops, 1972; Lotsberg et al., 1976; Cerf et al., 1977). The third group seems to carry the worst prognosis, as only three out of 10 patients were alive at the time of publication (Patterson et al., 1966; Gouffier et al., 1977; our case 4).

The authors are grateful to Mrs A. Gaste, L. Herbe, and $\mathrm{Mr} \mathrm{M}$. Wolfelsperger for their technical help.

\section{References}

Armstrong, B. K., Ammon, R. K., Finlay-Jones, L. R., Joske, R. A., and Vivian, A. B. (1973). A further case of chronic ulcerative enteritis. Gut, 14, 649-652.

Bayless, T. M., Kapelowitz, R. F., Shelley, W. M., Ballinger, W. F., and Hendrix, T. R. (1967). Intestinal ulceration. A complication of celiac disease. New England Journal of Medicine, 276, 996-1002.

Bayless, T. M., Yardley, J. H., and Hendrix, T. R. (1974). Coeliac disease and possible disease relationships. In Coeliac Disease: Proceedings of the 2nd International Coeliac Symposium, pp. 351-360. Edited by W. Hekkens and A. S. Peña. Stenfert Kroese: Leyden.

Belaiche, J., Modigliani, R., Modigliani, E., Galian A., and Bernier, J. J. (1977). Jéjuno-iléite ulcéreuse chronique non spécifique. Présentation d'un nouveau cas. Gastroentérologie Clinique et Biologique, 1, 553-560.

Bernier, J. J., Buge, A., Rambaud, J. C., Rancurel, G., 
Hauw, J. J., Modigliani, R., and Denvil, D. (1976). Polyneuropathies chroniques non carentielles au cours de la maladie coéliaque de l'adulte ( 2 observations avec lésions neuro-musculaires inflammatoires de vascularite). Annales de Médecine Interne, 127, 721-729.

Booth, C. C. (1974). Definition of adult coeliac disease. In Coeliac Disease: Proceedings of the 2nd International Coeliac Symposium, pp. 17-22. Edited by W. Hekkens and A. S. Peña. Stenfert Kroese: Leyden.

Case Records of the Massachusetts General Hospital (1969). New England Journal of Medicine, 280, 885-894.

Cerf, M., Gouerou, H., Marche, C., L'Hirondel, C., and Debray, C. (1977). Jéjunoiléite ulcéreuse diffuse: intérêt diagnostique de la jéjunoscopie. Gastroentérologie Clinique et Biologique, 1, 571-576.

Cooke, W. T., and Asquith, P. (1974). Introduction and definition. In Coeliac Disease. Clinics in Gastroenterology, 3, 3-10.

Cooke, W. T., and Smith, W. T. (1966). Neurological disorders associated with adult coeliac disease. Brain, 89, 683-722.

Corlin, R. F., and Pops, M. A. (1972). Nongranulomatous ulcerative jejunoileitis with hypogammaglobulinemia. Clinical remission after treatment with gammaglobulin. Gastroenterology, 62, 473-478.

Davidson, A. R. (1969). Recurrent benign ileal ulcer occurring with the coeliac syndrome. British Medical Journal, 3, 341.

Dowling, R. H. (1972). Non-responsive coeliac disease (Clinicopathological Conference). British Medical Journal, $3,624-631$.

Gouerou, H., Redelsperger, P. Y., Galian, A., Dervichian, M., Pappo, E., and Cattan, D. (1977). Jéjuno-iléite ulcéreuse chronique avec malabsorption. Gastroentérologie Clinique et Biologique, 1, 561-570.

Gouffier, E., Phan, A., Paraf, A., Boddaert, A., and Chevrel, J. P. (1977). Jéjuno-iléite ulcéreuse d'évolution récurrente. Étude opératoire et endoscopique d'un nouveau cas. Gastroentérologie Clinique et Biologique, 1, 545-552.

Goulston, K. J., Skyring, A. P., and McGovern, V. J. (1965). Ulcerative jejunitis associated with malabsorption. Australasian Annals of Medicine, 14, 57-64.

Himes, H. W., Gabriel, J. B., and Adlersberg, D. (1957). Previously undescribed clinical and postmortem observations in non-tropical sprue: possible role of prolonged corticosteroid therapy. Gastroenterology, 32, 60-71.

Hindle, W., and Creamer, B. (1965). Significance of a flat small-intestinal mucosa. British Medical Journal, 2, 455-458.

Jeffries, G. H., Steinberg, H., and Sleisenger, M. H. (1968). Chronic ulcerative (nongranulomatous) jejunitis. American Journal of Medicine, 44, 47-59.

Jones, P. E., and Gleeson, M. H. (1973). Mucosal ulceration and mesenteric lymphadenopathy in coeliac disease. British Medical Journal, 3, 212-213.

Karz, S., Guth, P. H., and Polonsky, L. (1971). Chronic ulcerative jejunoileitis. American Journal of Gastroenterology, 56, 61-67.

Klaeveman, H. L., Gebhard, R. L., Sessoms, C., and Strober, W. (1975). In vitro studies of ulcerative ileojejunitis. Gastroenterology, 68, 572-582.

London, D. R., Bamforth, J., and Creamer, B. (1961). Steatorrhoea presenting with gastrointestinal protein loss. Lancet, 2, 18-19.

Lotsberg, J., Teisberg, P., Myren, J., and Serck-Hanssen, A. (1976). Chronic ulcerative, non-granulomatous jejunitis. Scandinavian Journal of Gastroenterology, 11, suppl. 38, 24 (Abstract).

Modigliani, R. (1977). Les duodéno-jéjuno-iléites chroniques non spécifiques. Une entité anatomo-clinique de nosologie discutée. Gastroentérologie Clinique et Biologique, 1 , 501-506.

Moritz, M., Moran, J. M., and Patterson, J. F. (1971). Chronic ulcerative jejunitis. Report of a case and discussion of classification. Gastroenterology, 60, 96-102.

Neale, G. and colleagues (1970). A case of malabsorption, intestinal mucosal atrophy and ulceration, cirrhosis and emphysema (Clinicopathological Conference). British Medical Journal, 3, 207-212.

Nyman, E. (1949). Ulcerous jejuno-ileitis with symptomatic sprue. Acta Medica Scandinavica, 134, 275-283.

Patterson, M., Ong, H., and Drake, A. (1966). Protein-losing enteropathy. Report of two new cases. American Journal of the Medical Sciences, 251, 563-569.

Seliger, G., Goldman, A. B., Firooznia, H., and Lawrence, L. R. (1973). Ulceration of the small intestine complicating celiac disease. American Journal of Digestive Diseases, 18, 820-824.

Shiner, M. (1963). Effect of a gluten-free diet in 17 patients with idiopathic steatorrhea. A follow-up study. American Journal of Digestive Diseases, 8, 969-983.

Smitskamp, H., and Kuipers, F. C. (1965). Steatorrhoea and ulcerative jejunoileitis. Acta Medica Scandinavica, 177, $37-42$.

Stuber, J. L., Wiegman, H., Crosby, I., and Gonzalez, G. (1971). Ulcers of the colon and jejunum in celiac disease. Radiology, 99, 339-340.

Trier, J. S. (1973). Celiac sprue disease. In Gastrointestinal Disease. Pathophysiology. Diagnosis and Management, pp. 864-885. Edited by M. H. Sleisenger and J. S. Fordtran. Saunders: Philadelphia.

Wayte, D. M., and Helwig, E. B. (1968). Small-bowel ulceration-iatrogenic or multi-factorial origin? American Journal of Clinical Pathology, 49, 26-40. 